\title{
LXVIII. A monograph of the genus Teredo of Linné, with descriptive characters of the species in the British Museum
}

\author{
John Edward Gray Esq. F.G.S.
}

To cite this article: John Edward Gray Esq. F.G.S. (1827) LXVIII. A monograph of the genus Teredo of Linné, with descriptive characters of the species in the British Museum , Philosophical Magazine Series 2, 2:12, 409-411, DOI: 10.1080/14786442708674441

To link to this article: http://dx.doi.org/10.1080/14786442708674441

电 Published online: 10 Jul 2009.

Submit your article to this journal $₫$

Џll Article views: 3

Q View related articles $\sqsubset$ 
vided with triangular horn-like projections, and the tail being shorter than the body, and very thick and compressed at the base. In naming the species, I think that I cannot do better than dedicate it to its scientific and industrious proprietor, in whose collection it has been for a considerable time.

Chameleo Brookesiana.

Superciliis elevatis angularibus, denticulatis; occipite plano; fronte concavo; squamis parvis irregularibus; caudâ brevi basi compresso-incrassatâ dorsi lateribus, mento antice, membranorumque marginibus serie squamarum parvarum spinosarum instructis.

Inhab. Mus. Dom. Brookes.

Length $2 \frac{1}{4}$, body $1 \frac{1}{4}$, tail 1 , inches long.

Eyebrows elevated triangular, edges denticulated, innerside keeled, denticulated; forehead concave, especially in the centre; cheeks nearly flat; occiput flat with a slightly elevated ridge on each side, commencing from the tip of the superciliary elevations and nearly meeting on each side; head covered with small irregular scales; front of chin with 4-6 spine-like scales ; body and tail compressed, edges not denticulated; side of the back just at the origin of each of the ribs, with a series of rather large conical spine-like scales, and the legs with scat-. tered similar scales; rest of the scales of the body and tail small and irregular; tail base very thick, compressed.

The above-described individual is probably young. Nothing is known of its country; but it is probably from Africa.

P.S. Being engaged on an illustrated monograph of this genus, I shall be happy to see any specimen that may be in private collections.

J. E. G.

British Museum, Nov. 1, 1827.

LXVIII. A Monograph of the Genus Teredo of Linné, woith descriptive Characters of the Species in the British Museum. By JoHN EDWard GraY, Esq. F.G.S. \&c.*

THIS genus is best distinguished from Pholas by the absence of the back-valves, and by being always provided. with a shelly sheath. The pallet at the sides of the trachea of the animal appears to form a very good character to distinguish the species.

* Pallet unknoren (probably like the next).

Fistulana personata, Lam. A. M. Teredina personata, Lam. Ann. Mus. xii. t. 43. f. 67. Teredo. Sow. Foss. Shells.

Tubes cylindrical —? Shell globular. Valves as long as high. Anterior gape, an equilateral triangle; hinder gape ovate. Front lobe of the valves recurved, hinder lobe concen-

- Communicated by the Author.

New Series. Vol. 2. No. 12. Dec. 1827. $3 \mathrm{G}$ trically 
trically striated, internal tooth —_? Pallet? Fossil : Highgate.

Teredo antenauta. Sow. Foss. Shells.

Differs from the above in being larger; but I have no specimen to make an accurate description. Fossil: Highgate.

Serpula arenaria, Linn. ed. 10. Serpula polythalama, Linn. Septaria arenaria, Lam. Teredo, Home, Phil. Trans. and Anat. Comp. ii. t. 41. 4. Rumph. t. 41. f. D. E. Seba, iii. t. 94.

Tube very large, club-shaped, thick, behind closed, rounded, upper part divided into two tubular canals.

The valves are not in the Museum; but it is evidently a Teredo, and the division of the mouth is not enough to form a genus, as it is partially found in other species.

* Pallet broad lamellar.

Teredo navalis, Linn. Turton. Sow, Gen. Turton, Bivalves.

Adanson, Acad. Sci. Par. t. 9. f. 1-8. cop. Ency. Méth. t. 187. f. 1-3. and t. 167. f. 4. 5 .

Tubes long subcylindrical, tortuous end chambered. Shell globular, anterior gape roundish triangular; hinder one ovate lanceolate; the lower edge of the anterior lobe straight. Valves two-thirds as long as high; internal process broad, parallel to the valves; pallets broad, ovate, lamellar and blunt.

Teredo Malleolus. Turton, Bivalves. t. 2. f. 19. The pallet,

"Shell with the valve earshaped behind, and the auricules reflected. The pallet transverse mallet-shaped." Turt.

Teredo nana. Turton, Bivalves, t. 2. f. 6.7.

"Shell with the valves rounded, and without auricules behind, a strong tooth on the margin above the tooth." Turt. Bivalves.

*** Pallet ovate lamellar, end denticulated. Fistulana, Iram. Teredo Clava, Gmel. Fistulana gregata, Lam.

Ency. Méth. t. 167. f. 6-15.

Tubes club-shaped, contorted, aggregate and rounded, closed; mouth half-divided lamellar; shell ring-like, valves very short and high; front gape rounded; hinder one ovate; internal tooth linear and dilated hatchet-shaped; pallet broad lanceolate and acute; sides denticulated.

Fistulana corniformis, Lam., which I have not seen, does not appear to differ by the figures much, if at all, from this species.

The other species of Fistulana of Lamarck are all the cases of Gastrochana, except perhaps Fistulana clava, which if it does form a separate genus, it must be placed near the Gastrochene, and not with the Teredines.

**** Pallet long, base setaceous, end subarticulately divided, sheathed and pinnately lobed.

Teredo bipalmulata, Lam. Syst. T. palmulatus, Lam. Hist. Taret de Pondicherry, Adanson, Acad. Sci. Par. 1759. t. 9. f. 12. 
Tulbes cylindrical, thin ; shell ovate, globular; front lobe narrow triangular, lower edge rounded, very finely concentrically striated, central band thin; hinder portion smooth, the hinder dorsal edge ovate, expanded (not recurved) serving for the attachment of the abductor muscles; internal tooth broad, compressed sickle-shaped, at right angles with the inner side of the shell. Pallets base short, setaceous end compressed, end broad, pinnated and articulated. Sumatra: Mr. H. Stuchbury.

Teredo carinata. $\mathrm{n}$.

Tubes long, cylindrical; shell subglobular; front lobe triangular, lower edge straight, rather oblique, concentrically furrowed; medial band thin; hinder portion concentrically wrinkled, posterior dorsal margin expanded, recurved, parallel with the hinge; edge deeply keeled internally; internal tooth compressed, curved, placed obliquely with respect to the inner surface of the valve. Pallet base short, setaceous end compressed, end broad, linear lanceolate, pinnately articulated. Sumatra: Mr. H. Stuchbury.

Teredo bipennata, Turt. Conch. Dict. f. 28. 40. Teredo navialis. Home, Phil. Trans. and Comp. Anat. ii. t. 43. (bad).

Exactly like the latter in shape, but twice as large, and the front lobe is rather larger, and the hinder portion nearly smooth, and the inner edge is not so much keeled; and the pallet differs in having a very long setaceous stern 6 inches long), and in the end being short and pinnately articulated, with the ends of the joint long and filiform. "Tube thick, strong, without any transverse concamerated partitions." Turton. Drifted wood, British Channel. J. Bulwer, Esq.

In the above disposition I have studiously avoided giving any new names to the species, which is too much the fault of modern works.

In this arrangement of the genus, I have united four genera of Lamarck, but they appear to have been founded on very slight grounds.

I am informed by Professor Blainville, that our Teredo is not the Teredo navalis of French naturalists, and that he has called the one here described $T$. nigra. I am certain that is the one figured by the authors to which I have referred, and the older figures are so bad that it is impossible to determine whether theirs is distinct.

The Teredo dorsata is a kind of Pholas, being destitute of any tube, and being provided with back-valves. It is perhaps the link that connects the two genera.

LXIX. Meteorological Register kept at Funchal, in Madeina, in the Year 1826; \&c. By C. Heineken, M.D. 